\title{
African Past, American Future: Uplift Ideology in Early 20th Century Opera
}

\section{Rachel Hujsa \\ University of Florida}

Faculty Mentor: Laura Dallman, Department of History

\begin{abstract}
This paper explores how two African American composers, Scott Joplin (c. 1868-1917) and Harry Lawrence Freeman (1869-1954), advocated for Black Advancement and uplift ideology through their syncretic operas in the early 1900s. Joplin and Freeman were intimately conscious and supportive of national debates for Black Advancement, propelled especially by W.E.B. DuBois, and both employed rhetorical strategies paradigmatic of the movement. They were both interested in showing White and Black Americans alike that African American music, such as gospel, spiritual, and ragtime, could be held to the same high esteem as the music of the Western canon, just as Black academics often endeavored to prove their intellectual prowess to their White counterparts. To this end, Joplin and Freeman combined "Black" music and classical styles in their operas to declare the equality and richness of an integrated sound. The thematic content of these operas, Treemonisha (1911) and Voodoo (1928), respectively, interact with the Black Advancement movement's drive for progress and education as well. They present Black Americans' struggle for modernity as a conflict between the "superstitious" West African religious customs still ingrained in emancipated communities and Christianity. Though many critics and listeners are understandably uncomfortable with the assimilationist or even white supremacist connotations of abandoning African traditions for Christianity, it is important to note that the culture of Christianity these composers exalt is purely African American. This article argues that Joplin and Freeman's narrative struggles within their operas, though certainly open for criticism by modern audiences, are not between Blackness and Western assimilation but between their vision of an equally Black past and future.

Keywords: Black Advancement, Black Opera, Scott Joplin, Harry Lawrence Freeman
\end{abstract}

\section{African Past, American Future: Uplift Ideology in Early 20th Century Opera}

In 1998, Tupac Shakur's record labels, Amaru Entertainment, Death Row Records, and Interscope Records, released a posthumous Greatest Hits album containing Shakur's most popular tracks, including the yet-unreleased song, "Changes." In "Changes," Shakur raps about the chasm of racism separating Black and White Americans, while expressing the desire to heal generational trauma caused by social and economic discrimination. Yet despite circumstances out an individual's control, Shakur also calls upon African Americans to make changes in their personal lives: 
Let's change the way we eat

Let's change the way we live

And let's change the way we treat each other

You see, the old way wasn't working

So it's on us to do what we gotta do to survive.

While Shakur recognizes that Black people across America suffer due to systemic challenges and oppression, the song's climax reiterates a mantra of self-sufficiency and personal growth. To Shakur, a real change in Black communities must come from public and personal spheres. The world outside can ebb and flow politically, but Shakur believes that "it's on us...to survive" (Shakur, 1998).

"Changes" exemplifies a century-long tradition of political uplift among Black writers and musicians, from Rosamond and James Weldon Johnson's "Lift Ev'ry Voice and Sing" in 1900 to Sam Cooke's "A Change is Gonna Come" in 1964. As Shakur wants to do away with the "old ways" of drug abuse, poor nutrition, and violence that continue to affect Black communities, the African American artists who came before him sang about moving past oppression, slavery, and segregation, into an equal and progressive age.

Black classical music composers in the early 1900s, including Scott Joplin and Harry Lawrence Freeman, also argued for racial uplift and Black Advancement. These composers drew their inspiration from different, yet related, ideological and aesthetic places, resulting in the distinctive genre of Negro Grand Opera. Like the French Grand Opera of the mid 19th century, Joplin and Freeman's operatic works included structural elements such as overtures, large crowd and dance scenes, several acts, and political themes (Heubner, 1989). However, Negro Grand Opera and French Grand Opera are not historically nor thematically related beyond these key elements.

Joplin's Treemonisha (1911) is a tale about progress. He implores African Americans to abandon past African traditions and embrace Western education, modernity, and Christianity. H. Lawrence Freeman, on the other hand, draws inspiration from grand African civilizations, myths, and religions, in his opera, Voodoo (1928). The central narrative of the opera is a conflict between Christianity and Voodoo, in which Christians ultimately triumph over a Voodoo queen. The literary and aesthetic concept of "Africa," which has functioned as both a spectacle enjoyed by non-Blacks and a cultural backbone for pan-Africanists, functions throughout Freeman's work as a central feature, and as an ideological crossroads on the way to modern Black 
Advancement (Hochschild, 1998). In essence, Freeman and Joplin's arguments for advancement came, respectively, from an African past and an American present, culminating in idiosyncratic and distinctive African-American operas. This article will explore how these arguments took shape in classical music forms.

\section{Uplift Ideology and Double Consciousness in African American Music}

The term "uplift ideology," as utilized by this paper, is defined by musicologist Lawrence Schenbeck in Racial Uplift and American Music, 1878-1943 (2012), simply, as an ideology meant to encourage "Black's material and spiritual advancement....by changing the attitudes and practices of Whites, especially the White leadership elite" (p.4). Uplift ideology is a "survival strategy," in which African Americans were forced to interact and "negotiate" with the "dominant culture" to prove they deserved equality and worth in American society (p.6).

Joplin's and Freeman's deliberate choice to write in a European style is not inherently antiBlack or reflective of imperialist attitudes, today known as "internalized racism." This choice was a political strategy ushered in by great Black intellectuals such as W.E.B. DuBois. This strategy entailed proving without a shadow of a doubt that Black people could perform, sing, dance, write, and even amass wealth, as well as Whites. Freeman was undoubtedly aware of this strategy. In his unpublished monograph, Freeman discussed holding a social experiment in which a Black opera singer would perform behind a curtain for a White audience. When the curtain is drawn back, his hypothetical audience would be shocked to find out that a Black singer could so masterfully masquerade as a White vocalist, proving that African American singers, when classically trained, were indistinguishable from their White counterparts (Freeman, 1921).

According to Schenbeck, writing European-style music and injecting it with Black musical elements provided a sort of "cultural vindication" as a response to minstrelsy. The fact that Black men could successfully compose not just ballets and symphonic poems but grand operas in European traditions contradicted American ideas about where people of color belonged in the classical world and the Global North entirely. Freeman and Joplin proved that Black musicians were not merely students of Western thought, but propagators of new and exciting art music via a combination of European and African American forms. 


\section{Contemporary Criticisms}

Many critics and scholars have expressed discomfort with Joplin's and H. Lawrence Freeman's approach to uplift ideology, largely because these ideas do not suit the narrative of contemporary social justice movements. Klaus-Dieter Gross (2000) describes Treemonisha and Joplin's philosophies as "elitist," and claims that "Treemonisha's education and access to the white realm of knowledge...empowers her and makes the villagers recognize her superiority" (p. 394). According to Sarah Schmalenberger, Voodoo follows in this familiar strain, touting Christianity over West African-inspired Voodoo gods (Schmalenberger, 2006).

Furthermore, many "resistance-oriented" Africanists point to Africanisms, such as the resilience of Voodoo and its West African ancestor, Vodun, in the Americas, as proof of enslaved people's strength in the face of cultural annihilation. The ideological backbone of Treemonisha is the notion of progress through Western education, and this "onward march" entails letting go of treasured African traditions that slaves and their descendants relied upon to prevent their "social death" at the hands of their masters (Hartman, 2006). The fact that both Joplin and Freeman's operas exalt Christianity over African religions is understandably uncomfortable for many historians and musicologists. According to Paula Seniors, however, Black intellectuals at the turn of the 20th century often demonstrated the "ideology of uplift [by] maligning African traditions" and "[revolting] against anything connected with slavery" (Seniors, p.2). Thus, it is more useful to view Treemonisha and Voodoo as strategic, though contemporarily imperfect, products of their time, that are useful in discussing uplift ideology in the early 1900s as understood by musicians and other artists.

\section{Scott Joplin's Treemonisha}

The music of Treemonisha is an unforgettable blend of ragtime, gospel, and Wagnerian classical music, with African-American syncopation wedded throughout 3 acts and 27 numbers. Treemonisha, in operatic style, consists of an overture to the first act and preludes to the first and second acts, large dance numbers, arias, and recitatives. Most of the opera is thoroughly European, and the rag elements specifically shine through in the dance numbers (Joplin, 1911).

The vocal score requires virtuosity. The titular character's part soars to some of the highest notes in a soprano's range, including frequent octave jumps to a B5 in the finale "A Real Slow 
Drag." The libretto, which Joplin wrote himself, is personal and witty, and shows his own relationship with and love for the American south. In total, the score lays out an expectation of skill and virtuosity from the Black opera singers Joplin intended to highlight in one of the first all-Black operas ever written, decades before George Gershwin penned Porgy and Bess.

Equal in interest to Joplin's use of syncopation and poetic flair in Treemonisha's score and libretto is his exploration of contemporary ideas about Black Advancement. Like Shakur, Joplin speaks directly to Black communities about what he feels will benefit African Americans and uplift the race, focusing not as much on systemic issues but on personal choices. The entire opera is centered around a well-educated Black woman named Treemonisha, who is tasked with shepherding her small southern community near Texarkana, Arkansas, Joplin's birthplace, to enlightenment through Western education. To do so, she must convince her community to cast aside African religious customs and superstitions and embrace Christianity. The main villain in the opera is the conjurer Zodzerick, who is reminiscent of the African trickster god, Papa Legba. When the conjurer tries to sell "magic bags" to the sharecroppers, likely based off of African gris-gris, or packages filled with small ritual objects, Treemonisha finally stands up to him, and orders him to leave. After a series of trials, Treemonisha finally succeeds, culminating in the

final number, "A Real Slow Drag," in which all of the sharecroppers and townspeople sing about their newly-formed collective desire for progress and modernity (Joplin, 1914):

\section{Marching onward, marching onward, Marching to that lovely tune; Marching onward, marching onward, Happy as a bird in June. Sliding onward, sliding onward, Listen to that rag.}

Joplin believed that to uplift the race, Black people must leave behind a past of ignorance and make the choice to embrace modernity, Christianity, and education. This idea is also revealed through the text of the libretto. Joplin purposefully contrasts Christian and African religions in "Good Advice" and the following number "Superstition." "Good Advice" is sung by a preacher and enumerates Christian values. "Superstition," sung by the West African conjurer Simon, represents various superstitions, which are presented as illogical and crude (p.17): 
If you are eatin' food wid ease, An' drawin' pleasant breath,

Be careful dat you do not sneeze, Because 'tis sign of death

As written in the libretto, the educated Treemonisha speaks in "common" English and embodies elegance, not unlike a European prima donna, while the uneducated laborers and conjurers alike speak in African American Vernacular English. She is referred to as "the only educated person of our race" with a "level head" (p.3). Treemonisha also has a White woman to thank for her intellectual success. Treemonisha's adopted mother sings in an aria: "There being no school in the neighborhood/ A white lady undertook your education" (p.11). Treemonisha's intelligence and ability to lead her community into the future is not borne necessarily of Black excellence in of itself; it is reliant on Whiteness.

Through these contrasts - foolish superstition and Christian advice, homeliness and sophistication - Joplin implicitly and explicitly endorses Western culture, and through this, the uplift of African Americans. More specifically, when Treemonisha educates her community, she is accepted by the people around her, and in turn accepts her place as a leader in a fully Black society. Joplin's vision of a future is firmly seated in African American communities, and even more importantly, in the education of African American women. Treemonisha represents both the supremacy of a Western education, but also collective Black pride and revolutionary action.

\section{Harry Lawrence Freeman's Voodoo}

Freeman's most famous opera is Voodoo, written in 1914 and performed in 1928. Like Treemonisha, Voodoo presents audiences a blend of different styles, including jazz, folk, and, as mentioned in the former opera, Wagnerian operatic ideas. Narratively, Voodoo is very similar to Treemonisha in that it shows a battle of sorts between Christianity and African religions. Voodoo takes place in Louisiana shortly after the Civil War. Voodoo's plot depicts a love triangle between Lolo, the Voodoo Queen, Cleota, a house servant and Mando, the plantation boss. Mando is in love with Cleota, and Lolo, jealous and angry, plans a Voodoo ritual to kill Cleota. The ritual is detailed and musically rich. Although Lolo's intense and dramatic arias frame the ritual, they are clearly the focal point of the opera. Freeman shows at least cursory knowledge of Voodoo, and its African predecessor Vodun. Lolo passes out amulets, a staple of Vodun and Voodoo ceremonies, to the other servants taking part in the ritual, and calls upon the Snake God, an actual deity in Voodoo, to do her bidding. 
However, Lolo's plans are foiled when Mando and Lolo's own mother, Chloe, stop the ritual through passionate appeals to Christianity. Lolo is shot, and the Voodoo Queen, representative of enslaved people's doomed reliance on African religion, dies. Though Lolo does not survive the plot of the opera, her narrative dominance is undeniable. She is depicted as powerful, albeit misguided, and is by far the most dynamic character in the opera, with the most harmonically adventurous (though usually dissonant) solos and arias. Freeman's body of work as a whole includes many African characters and myths. Voodoo gives us just a taste of the importance Freeman gives African themes in his operas.

David Gutkin positions Freeman's work within two "civilizationist" theories: a utopian "historiography of decline" that proclaimed the former greatness and moral superiority of African civilizations, and the other, a "'historiography of progress' that asserted the promise of African and Afro-diasporic advancement in the future" (Gutkin, 2019, p.743). Gutkin draws these ideas from historian Wilson Moses. In his book, Afrotopia: The Roots of African American Popular History, Moses traces Afrocentrist ideologies in Black communities throughout American history. Moses contends that "Afrocentrists are obsessed with demonstrating that Black cultures have met the criteria of being civilized" in the past, because they felt this could prove to the ruling class that "African Americans could and should be educated, as other American citizens were" (Moses, 1998, p.238). Procuring education was paramount in Black Advancement ideology, and with the past securely Africanized and idealized, "there developed...the idea of unstoppable progress toward a racially enlightened and egalitarian society in the future" (Moses, 1998, p.238). Furthermore, he claimed in an undated newspaper article, "The Negro in Grand Opera," that much of Western "literature, science and art were originated by the people of Africa," and that this ability to achieve "great learning...lay dormant in the soul of every Black man and woman throughout the centuries" (Freeman, ND). Freeman's concept of an African American future was wrapped up in an African past, and indeed was almost contingent upon it, because an awakening of Black consciousness from past civilizations was necessary to stir modernity and advancement. Freeman chose to make music about African legends and civilizations in order to convince Black and White listeners alike that progress and equality both for African Americans and Africans was on the horizon. 
Thus, Freeman's view of Africans and Africa is complex. He depicts African culture with dignity, and as deserving of a history in some places, but also as primitive, and waiting to be enlightened in others. Freeman's relationship with Africa and Black history can best be described by this excerpt from his monograph (Freeman, 1921):

The Negro will be his own historian in song and drama at the coming pageant. There will run through his story the cadence of his climbing feet, both in the weird beating of the African tom-tom and in its modern elaboration, the monotonous minor of the blues. But above that cadence will rise like the sound of lifting wings the exaltation of the spirituals. The Negro has come down the centuries of this hour in pathos and patience, in tragedy and tears, but always with a rainbow cast about his shoulders. He has lived by his dreams. Today he reads the future of his race in the fruitful lives of men who have distinguished themselves as educators, as scientists, as writers, as painters, and greatly as composers of music. Dreams are coming true.

As a contemporary Black artist and composer, Freeman found it his right and perhaps even his duty to craft a new Black identity that enveloped a lost history as well as a brighter future, treading a very delicate line between accepting European religious and cultural hegemony, while yearning for African consciousness. A development of the past was an integral part of this process, and through this past would come a future.

\section{Joplin, Freeman, and Christianity}

Freeman described music in his monograph as "a sacred trust from God to man...the devout expression of the soul..." (Freeman, 1921, p.7). As a deeply religious man, it is unsurprising that Freeman would link his two passions for Christ and opera. In Voodoo, Freeman casts African religion both as a powerful symbol of the past, but also something that must be vanquished in favor of Christianity. A similar story occurs in another one of Freeman's operas, The Martyr. The Martyr takes place in Egypt, and the plot is, in essence, about an Egyptian man who converts from a paganism to Judaism, and is then killed for his conversion, thus earning the opera's namesake. Freeman's rosy vision of an African past is invariably interspersed with a religious struggle for monotheism. At first glance, like in Joplin's Treemonisha, Freeman's implicit argument for the adoption of Christianity in Black spheres over African religions can appear to be elitist, drawing some ire from modern audiences. However, it is important to understand how many African Americans, and Freeman in particular, actually viewed Christianity in the early 1900s. Rather than as a bastion of White supremacy, many Black Christians, including Freeman, 
viewed Christianity as a vehicle for uplift and spiritual fulfillment stemming not from Europe, but from Africa.

The Color of Christ: The Son of God and the Saga of Race in America (2012) by Edward J. Blum and Paul Harvey chronicles how Western depictions of Jesus have metamorphosized through time and in different communities. Christ's face and persona has varied widely throughout American culture history. Christ can be wielded as an emblem of oppression by some and a powerful symbol against racism by others. Blum and Harvey conclude the White and Black Americans viewed, and still view, Christ in fundamentally different ways. While many Whites used and still use Christian doctrines to rationalize imperial expansion and paternalistic foreign policies, many Black Christians viewed Jesus as an oppressed, Brown-skinned purveyor of social and economic justice (Blum and Harvey, 2012).

Some African American's perceptions of Jesus differed sharply from even these examples, such as those belonging to Marcus Garvey, a contemporary of Booker T. Washington and W.E.B. Du Bois. Blum and Harvey argue that Garvey's new notion of what would later be called a "Black Jesus" was "part defiance to White supremacy, part embrace of Blackness" (p.161). Though Freeman and Joplin certainly held more integrationist perspectives than Garvey, as Black men who were proud of their race, there is no conceivable way they would have accepted a White supremacist's vision of Christ.

It is possible that Joplin, another African American man living in New York City, felt the same way. Chloe's character in Voodoo and the music she sings crystalizes this idea best. As the most benevolent character in the opera who takes part in vanquishing the Voodoo Queen, she does not sing protestant hymns or interject with grandiose Wagnerian melodies. Chloe's aria from act II makes uses the Blues scale and is heavily influenced by spiritual. Lolo is not defeated by so-called White Jesus by any means.

It is therefore likely incorrect to view Christianity's triumph over African religions in Voodoo and Treemonisha as an endorsement of Western culture and the White supremacy tied so closely to it in the early 20th century. It is more likely that Freeman and Joplin viewed this battle as a progression from superstition to African American intellectual modernity through the lens of Christianity, not as a religion of White supremacy, but as one that belonged to Blacks as well as 
Whites. The struggle is not between Blackness and Whiteness, but between an equally Black past and future.

\section{Conclusion}

Scott Joplin and Harry Lawrence Freeman were interested in uplift ideology and Black Advancement and wrote music aimed at promoting these ideals. Both composers attempted to prove that Black people were just as creative, talented, and artistically worthy as Whites while advocating for African Americans to embrace modernity. By combining Western and African American styles, both composers sought to show Whites the compatibility, but also the equality, of the two musical paradigms. They also attempted to prove to Whites that Black music - rag and the spiritual - were true artistic endeavors. Furthermore, Freeman pushed for Black Advancement and modernity through connecting African history with civilizationist theories and the past achievements of African peoples, while Joplin sought after the same goal through a firmly modern African American narrative about education and racial uplift. Through studying the works of composers, the ideologies, but also the aesthetics, of Black Advancement are revealed and better understood.

\section{References}

Berlin, Edward A. King of Ragtime: Scott Joplin and his Era. Oxford University Press, 1996.

Blum, Edward. and Harvey, Paul. The Color of Christ: The Son of God and the Saga of Race in America. Chapel Hill: University of North Carolina Press, 2012.

Freeman, H. L. (Ca. 1921-1940s). The Negro in Classical Music and Opera. Unpublished Monograph.

Freeman, Harry L. "The Negro in Grand Opera" (unidentified magazine article, ca. 1922-23). H. Lawrence Freeman Papers, 1870-1982, Rare Book and Manuscript Library, Columbia University Library.

Gutkin, David. The Modernities of H. Lawrence Freeman. (2019).Journal of the American Musicological Society 73(3), 719-779.

Hartman, Saidiya. Lose Your Mother. Farrar, Straus and Giroux, 2006.

Joplin, Scott. Treemonisha (1911) Libretto. Pegasus Opera Company, 2021. 
Joplin, Scott. Treemonisha. Scott Joplin, monographic, 1911. Image.

Joplin, Scott. Treemonisha, “A Real Slow Drag,” (New York: Scott Joplin), 1911, IMSLP.

Kirk, Elise. American Opera. Urbana: University of Illinois Press, 2001.

Ross, A. (2020, September 21). Black Scholars Confront White Supremacy in Classical Music. The New Yorker. https://www.newyorker.com/magazine/2020/09/21/black-scholars-confront-whitesupremacy-in-classical-music

Schenbeck, L. (2012). Racial Uplift and American Music, 1878-1943. The University Press of Mississippi.

Seniors, Paula. Beyond Lift Every Voice and Sing: The Culture of Uplift, Identity, and Politics in Black Musical Theatre. Columbus: The Ohio State University Press, 2009.

Shakur, T. (1998). Changes [Recorded by Tupac Shakur]. On Greatest Hits [MP3 File]. Santa Monica, California: Interscope Records.

Stanford, K. (2011). Keepin' It Real in Hip Hop Politics: A Political Perspective of Tupac Shakur. Journal of Black Studies, 42(1), 3-22. 